\title{
Urinary excretion of purine derivatives as an index of microbial-nitrogen intake in growing rabbits*
}

\author{
J. Balcells†̣, J. M. Ganuza, J. F. Pérez, S. M. Martín-Orúe and M. González Ronquillo \\ Departamento de Producción Animal y Ciencia de los Alimentos, Facultad de Veterinaria, \\ Miguel Servet 177, 50013 Zaragoza, Spain
}

(Received 17 February 1997 - Revised 14 October 1997 - Accepted 17 October 1997)

\begin{abstract}
Three experiments were carried out to establish a response model between intake and urinary excretion of purine compounds. In Expt 1 the relationship between the intake of purine bases (PB) and the excretion of total purine derivatives (PD) was determined in seven growing rabbits with a mean initial live weight (LW) of 2.03 (SE 0.185$) \mathrm{kg}$, aged $70 \mathrm{~d}$, each fitted with a wooden neck collar to prevent caecotrophagy. They were fed on five experimental diets formulated with different levels of nucleic acids $(0.00,3.75,7.50,11.25,15.00 \mathrm{~g}$ yeast-RNA $/ \mathrm{kg}$ diet $)$. The relationship between intake of purine $\left(x, \mu \mathrm{mol} / \mathrm{kg} \mathrm{W}^{0.75}\right)$ and total urinary PD excretion $(y$, $\left.\mu \mathrm{mol} / \mathrm{kg} \mathrm{W}^{0.75}\right), y=0.56+0.67 x\left(r^{2} 0.86 ;\right.$ RSD 0.338$)$, indicated that about $70 \%$ of duodenal PB were recovered as urinary PD and that the endogenous contribution was constant and independent of dietary PB supply. Endogenous excretion of PD (allantoin and uric acid) was measured in a second experiment using six rabbits fed on a purine-free diet and fitted with neck collars to avoid caecotrophagy. Basal daily urinary excretion values for allantoin and uric acid were 532 (SE 33.9) and 55 (SE 7.3) $\mu \mathrm{mol} / \mathrm{kg} \mathrm{W}^{0.75}$ respectively; xanthine and hypoxanthine were not found in urine samples and therefore the sum of allantoin and uric acid should comprise the total excretion of PD (588 (SE 40.1$) \mu \mathrm{mol} / \mathrm{kg} \mathrm{W}^{0.75}$ ). The xanthine oxidase $(E C$ 1.2.3.2) activity in plasma, liver, duodenum, jejunum and kidney was measured in a third experiment. The activities of xanthine oxidase in duodenal and jejunal mucosa, liver and kidney were: 0.61 (SE 0.095), 0.37 (SE 0.045), 0.035 (SE 0.001) and 0 units/g fresh tissue respectively and in plasma 2.96 (SE 0.094) units/l. The results show that urinary excretion of PD may be a useful tool to estimate duodenal PB input and microbial protein intake once the relationship between PB and N has been established in caecal micro-organisms.
\end{abstract}

Purines: Xanthine oxidase: Rabbit

As in ruminants, single-stomached herbivores have developed an especially large colon or caecum to maximize the microbial digestion of fibre. However, while ruminants are able to benefit nutritionally from the microbial mass leaving the rumen, microbial protein in single-stomached herbivores is a waste product contained in faeces. However, some single-stomached species have developed mechanisms to use such material, by combining selective retention in the caecum of fluid and small particles (as vehicles of microbial micro-organisms) with a form of coprophagy: caecotrophagy. For the sake of clarity the term caecotrophagy should be used only in relation to those animals able to produce two distinct types of faeces of different chemical composition and to consume only one of them: caecotrophes.

In growing rabbits, caecotrophagy may contribute from 15 to $38 \%$ of total protein intake (Hörnicke \& Björnhag, 1980; Carabaño et al. 1988; Fraga et al. 1991), this value being affected by several dietary factors such as fibre content (Hörnicke \& Björnhag, 1980) and total N or DM intake (Proto et al. 1968). Therefore, the caecum in rabbits constitutes a 'fermentation chamber' that can be manipulated in order to optimize the use of dietary protein. The optimization of caecal function has been limited by the

Abbreviations: CMC, carboxymethyl celluose; HEPES, N-2-hydroxyethylpiperazine-N'-2-ethanesulfonic acid; LW, live weight; PB, purine bases; PD, purine derivatives; PMSF, phenylmethylsulfonyl fluoride; VFA, volatile fatty acids; $\mathrm{XO}$, xanthine oxidase.

* This work was financed by Purina España S.A.

† Corresponding author: Dr J. Balcells, fax +34976 7616 12, email balcells@posta.unizar.es 
experimental difficulties of measuring accurately both production and intake of caecotrophes. Currently, existing methods are based on: (1) the utilization of wooden (or other material) collars to prevent caecotrophagy; (2) the establishment of caecum fistulas for the collection of caecal content. However, the use of both methods is restricted to short periods because in long-term experiments the results are always confounded by the fact that caecotrophagy is part of the normal physiological digestive process in rabbits. Moreover, it is assumed intrinsically in coprophagy trials that caecotrophes would be fully consumed, even though there is no clear evidence to confirm this (Proto et al. 1968). It should also be noted that the use of a collar and fistulation are procedures which normally affect voluntary DM intake.

Purine bases (PB) flowing to the small intestine can be estimated from urinary excretion of purine derivatives (PD; allantoin, uric acid, xanthine and hypoxanthine) once the relationship between duodenal input and urinary excretion of purine compounds is established. This technique has been extensively applied to sheep (Chen et al. 1990a; Balcells et al. 1991) goats (Lindberg et al. 1989) and cows (Verbic et al. 1990) to obtain duodenal flow of PB as an index of microbial-N flow. In rabbits and other caecotrophagous animals, the excess of duodenal PB, estimated from urinary excretion of PD, over those ingested in the diet is assumed to come from microbial sources. In these animals, urinary excretion of PD may also constitute a valuable index to estimate microbial protein intake from caecotrophagy. The objective of the present study was to establish a response model between duodenal flow and renal excretion of purine compounds in the rabbit, building it on: (1) the relationship between duodenal input and urinary output of purine compounds; (2) the determination of the endogenous contribution to urinary excretion; (3) the activity of the enzyme xanthine oxidase (EC 1.2.3.2; XO) in different tissues as a key step for purine metabolism.

\section{Materials and methods}

Expt 1: Relationship between purine base intake and urinary excretion of purine derivatives in growing rabbits

Animals. Seven New Zealand White male rabbits with a mean initial live weight (LW) of 2.03 (SE 0.185$) \mathrm{kg}$, aged
$70 \mathrm{~d}$, were used. Animals were maintained in metabolism cages for faeces and urine collection, and penned individually during the adaptation period, always under continuous lighting and with free access to drinking water.

Diets. Five experimental diets (Table 1) were formulated based on grass hay $(500 \mathrm{~g} / \mathrm{kg})$ and barley grain $(405 \mathrm{~g} / \mathrm{kg})$ supplemented with different amounts of yeast-RNA (Sigma Co., St Louis, MO, USA), (g yeast-RNA/kg DM: 0.00, diet $A ; 3.75$, diet $B ; 7 \cdot 50$, diet $C ; 11.25$, diet $D$ and 15.00 , diet $E$ respectively). Diets were given once daily at a restricted level $(50 \mathrm{~g} / \mathrm{kg} \mathrm{LW})$ to avoid feed refusals. Diets were sampled weekly.

Experimental procedures. Each experimental treatment was maintained for eight consecutive days, comprising $5 \mathrm{~d}$ adaptation and $3 \mathrm{~d}$ for faeces and urine collection. At $24 \mathrm{~h}$ after the start of the experimental period a wooden collar (50 $\mathrm{mm}$ i.d. and $270 \mathrm{~mm}$ o.d.) was fitted around the neck of each rabbit to avoid caecotrophagy, this being removed at the end of each experimental period. Diets were given following a complete $7 \times 7$ Latin square design where the five experimental diets were completed, along with two additional diets of similar characteristics but in which nucleic acids were supplied as a bacterial concentrate (EA$\mathrm{SACC}^{1026}$; Alltech, Inc., Nicholasville, KY, USA) (g EA$\mathrm{SACC} / \mathrm{kg} \mathrm{DM}, 37.5 \operatorname{diet} \mathrm{F}$ and $75 \operatorname{diet} \mathrm{G})$. However, analytical determination showed that the purine content in both diets $\mathrm{F}$ and $\mathrm{G}$ decreased progressively in the weekly samples and therefore data from the EA-SACC diets were removed and are not included in any of the subsequent report or discussions in the present paper. However, diets were supplied following the original schedule. Once the trial was finished, rabbits were fed on the basal diet before they were killed.

Sample collection. Daily urine was collected over $\mathrm{H}_{2} \mathrm{SO}_{4}$ $(100 \mathrm{ml} / 1$, final $\mathrm{pH}<3$ ), bulked for each animal and stored at $-20^{\circ}$. Faeces were collected after separation of hard and soft material (caecotrophes) and frozen immediately at $-20^{\circ}$. After the animals were killed by cervical dislocation, the caecum was excised and weighed. The $\mathrm{pH}$ of the caecal content was measured with a glass electrode $\mathrm{pH}-$ meter. Three samples of the caecal content were taken, two of them $(2 \mathrm{~g}$ each) were acidified with either $\mathrm{HCl}$ or $\mathrm{H}_{3} \mathrm{PO}_{4}$, and stored at $-20^{\circ}$ until the concentrations of $\mathrm{NH}_{3}-\mathrm{N}$ and volatile fatty acids (VFA) were determined. The third sample (10 g), obtained for microbial character-

Table 1. Diet composition ( $\mathrm{g} / \mathrm{kg} \mathrm{DM})$ of the experimental diets (A-E) used in Expt 1 and composition of the semipurified purine-free diet (PF) used in Expt 2

\begin{tabular}{lccccrr}
\hline Diet code ... & A & B & C & D & E & PF \\
\hline Ingredient & & & & & & \\
Grass hay & 500 & 500 & 500 & 500 & 500 & 0 \\
Barley straw & 0 & 0 & 0 & 0 & 0 & 554 \\
Barley grain & 405 & 405 & 405 & 405 & 405 & 0 \\
Starch & 0 & 0 & 0 & 0 & 0 & 296 \\
Casein & 75 & 71.2 & 67.5 & 63.7 & 60.0 & 130 \\
Yeast-RNA* & 0.00 & 3.75 & 7.50 & 11.25 & 15.00 & 0 \\
Vitamin-mineral complex† & 20 & 20 & 20 & 20 & 20 & 20 \\
\hline
\end{tabular}

"Provided by Sigma Co. (St Louis, MO, USA).

f Provided by Cyanamid Iberica (Madrid, Spain) with the following declared mineral and vitamin composition (g/kg diet): calcium carbonate 2.5; dicalcium phosphate 12.5; sodium chloride 3; Cu 3.5; $\mathrm{Zn} 7.7 ; \mathrm{Mn} 3.3$. Vitamins (mg/kg diet): $\alpha$-tocopherol 2.2 , retinol 540 , cholecalciferol 5. 
ization, was diluted immediately in anaerobic dilution solution (Bryant \& Burkey, 1953) and serially diluted under a stream of $\mathrm{CO}_{2}$. Portions $(1 \mathrm{ml})$ were inoculated anaerobically in Hungate tubes containing total, cellulolytic or amylolytic culture media. Cellulolytic and amylolytic media were prepared by replacing soluble sugars in the total medium by $30 \mathrm{~g} / 1$ ball-milled-cellulose (Sigmacell 20, S3504, Sigma) solution and soluble starch respectively. The remainder of the caecal content was diluted in a salinecarboxymethyl cellulose (CMC) solution $(9 \mathrm{~g} \mathrm{NaCl} / 1$, $1 \mathrm{~g} \mathrm{CMC} / 1,38^{\circ}$ ) and incubated for $5 \mathrm{~min}$ at $38^{\circ}$ followed by chilling at $4^{\circ}$ for $24 \mathrm{~h}$ to dislodge adherent bacteria. Diluted caecum content was squeezed through eight layers of surgical gauze and bacteria were isolated from the filtrate by differential centrifugation, $500 \mathrm{~g}$ for $5 \mathrm{~min}$, followed by two consecutive centrifugations of the supernatant fraction at $20000 \mathrm{~g}$ for $20 \mathrm{~min}$ at $4^{\circ}$. The resultant microbial pellets were freeze-dried for subsequent analysis.

\section{Expt 2. Endogenous excretion of purine derivatives}

Animals and feeding. Another set of seven New Zealand White male rabbits (LW 2.93 (SE 0.073) kg) of similar age (70 d) to those used in Expt 1 were given ad libitum a semi-purified purine-free diet containing (relative proportion): washed barley straw 0.55 , starch 0.30 , casein 0.13 and vitamin-mineral mixture 0.02 (Table 1). The semipurified diet was introduced by gradually replacing a commercial diet for $5 \mathrm{~d}$; after that animals received the purine-free diet for $8 \mathrm{~d}$ before the start of the urine collection. Animals were housed and kept under the same conditions as Expt 1.

Excreta collection. The procedures used for the collection of urine and faeces were as described in Expt 1.

\section{Expt 3. Xanthine oxidase activity in tissues and purine compounds in portal and peripheral blood}

Animals and sampling. A set of three New Zealand White male rabbits, with a mean LW of 2.88 (SE 0.060$) \mathrm{kg}$, aged $70 \mathrm{~d}$, were used. Animals were fed ad libitum during the growth period on a commercial diet (160 $\mathrm{g}$ crude protein $/ \mathrm{kg}$ ). Samples of portal and peripheral (heart) plasma were taken by direct extraction from pre-anaesthetized animals and tissue samples were taken after killing the animals by cervical dislocation.

Preparation of tissue extracts. Blood samples were collected into heparinized tubes and centrifuged at $3000 \mathrm{~g}$ for 15 min. Plasma samples were analysed within $2 \mathrm{~h}$. Procedures for extraction of liver samples were adapted from those described by Furth-Walker \& Amy (1987) and the extraction of the intestinal mucosa layer followed Reeds et al. (1997).

Liver and kidney were washed in cold $0.15 \mathrm{M}-\mathrm{KCl}$ and $1 \mathrm{~g}$ tissue was homogenized in $9 \mathrm{ml} 0.5 \mathrm{mM}$-EDTA in $0.05 \mathrm{M}-\mathrm{K}_{2} \mathrm{HPO}_{4}(\mathrm{pH} \mathrm{7.5})$ and centrifuged at $35000 \mathrm{~g}$ for $30 \mathrm{~min}$ at $4^{\circ}$. The supernatant fraction was dialysed for $24 \mathrm{~h}$ against the same EDTA- $\mathrm{KH}_{2} \mathrm{PO}_{4}$ buffer for $24 \mathrm{~h}$ and centrifuged at $35000 \mathrm{~g}$ for $30 \mathrm{~min}$ at $4^{\circ}$. The supernatant fraction was used for the assay.
Intestinal samples were taken from the duodenum and jejunum after the Treitz junction and the lumen was washed with cold $0.15 \mathrm{M}-\mathrm{KCl}$. After that intestinal samples were frozen immediately (using liquid $\mathrm{N}$ ) and defrosted within $2 \mathrm{~h}$ at $4^{\circ}$, then the lumen was washed with $0.05 \mathrm{M}-\mathrm{N}-2-$ hydroxyethylpiperazine- $\mathrm{N}^{\prime}$-2-ethanesulfonic acid (HEPES) buffer ( $\mathrm{pH} 7.5$ ) containing $0.25 \mathrm{mM}-\mathrm{EDTA}$ and $0.25 \mathrm{mM}-$ phenylmethylsulfonyl fluoride (PMSF). A sample of intestinal mucosa ( $1 \mathrm{~g}$ ) was removed by finger pressure along the portion of intestine, collecting the mucosa layer cells at the bottom in $9 \mathrm{ml}$ HEPES-EDTA-PMSF buffer. The extract containing the enzyme XO was then purified as for the liver samples but using HEPES-EDTA-PMSF buffer.

Xanthine oxidase activity. Activity of $\mathrm{XO}$ was measured as the rate of uric acid production when xanthine was incubated with tissue extracts as described by Chen et al. (1996).

\section{Chemical analyses}

Urinary and plasma PD (allantoin, uric acid, hypoxanthine and xanthine) were analysed by reverse-phase HPLC, using two Spherisorb C-18 ODS-2 $(4.6 \times 250 \mathrm{~mm})$ columns, according to the technique described by Balcells et al. (1992). After defrosting, a significant amount of mineral precipitation appeared in the jar containing urine. The precipitate was rediluted by shaking it with $100 \mathrm{ml}$ buffer (0.2 M-phosphate-glycerol; 90:10, v/v, pH 8-9) for $30 \mathrm{~min}$ and the resultant dilution was treated in the same way as urine samples. The values obtained were added to the urinary ones. Adenine and guanine in feeds $(50 \mathrm{mg})$, caecal bacteria $(15 \mathrm{mg})$, caecotrophes $(15 \mathrm{mg}$ ), and hard faeces $(100 \mathrm{mg}$ ) were determined by the same HPLC technique, after their hydrolysis with $2 \mathrm{ml} 2 \mathrm{M}-\mathrm{HClO}_{4}$ at $100^{\circ}$ for $1 \mathrm{~h}$, adding previously $0.20 \mu \mathrm{mol}$ allopurinol as an internal standard and neutralizing immediately with $4.5 \mathrm{M}$ KOH (Martín-Orúe et al. 1995). DM was determined by drying at $105^{\circ}$ to constant weight. $N$ was measured by the Kjeldahl method. Neutral-detergent fibre and acid-detergent fibre were determined according to the procedure described by Van Soest et al. (1991) using an amylolytic pre-treatment. VFA were analysed by GLC following the procedure described by Jouany (1982) and caecum $\mathrm{NH}_{3}$ using the method proposed by Chaney \& Marbach (1962).

\section{Statistical analysis}

Values from Expt 1 were examined by ANOVA as an incompletely balanced block design (Youden square) where five treatments were tested against seven animals during seven experimental periods. Analyses were performed following the procedure described by Box et al. (1978). Treatment sums of squares were partitioned into two orthogonal contrasts to test linear and quadratic responses to $\mathrm{PB}$ suplementation. Regression analysis was also used to describe this response (Steel \& Torrie, 1980). In the third experiment uric acid production was calculated using a standard curve established with uric acid and described linearly in the liver and as a monoexponential 
function of the incubation time $\left(y=a+b\left(1-\mathrm{e}^{-c t}\right)\right)$ as described by Chen et al. (1996) in the intestinal mucosa and plasma. One unit of $\mathrm{XO}$ activity was defined as $1 \mu \mathrm{mol}$ uric acid produced per min at $37^{\circ}$ in excess of substrate.

\section{Results}

Feed intake was restricted in Expt 1 to $50 \mathrm{~g} / \mathrm{kg} \mathrm{LW}$ per d in order to avoid feed refusals and to maintain a stable supply of nutrients. In such conditions, animals increased LW from 2.03 (SE 0.078) $\mathrm{kg}(70 \mathrm{~d}$, initial $\mathrm{LW}$ ) to 2.96 (SE $0.062) \mathrm{kg}(128 \mathrm{~d}$, final LW) so they showed a moderate LW gain rate $(16 \mathrm{~g} / \mathrm{d})$ which was not different among experimental periods $(P>0 \cdot 10)$. In Expt 2 , animals remained in good health throughout the experiment, but one animal failed to maintain an acceptable level of DM intake and the corresponding observations of endogenous excretion were removed. Animals could not meet their maintenance requirements and they lost weight, but the loss was less than $0.7 \%$ of the initial body weight.

\section{Caecum characteristics}

The average $\mathrm{NH}_{3}$ concentration in caecal content was 9.3 (SE 0.93 ) $\mathrm{mmol} / \mathrm{l}$ and the $\mathrm{pH}$ was constant among animals with a mean value of 6.4 (SE 0.08 ). The total concentration of VFA in caecal content was 73 (SE 3.2) $\mathrm{mmol} / \mathrm{l}$ with acetate comprising $80.5 \%$ of the total followed by butyrate $(9.4 \%)$ and propionate $(5.9 \%)$. The total count of microorganisms in the caecum was $10^{9}$ micro-organisms $/ \mathrm{ml}$ with the highest proportion being amylolytic micro-organisms $\left(12 \times 10^{6}\right)$ whereas the count of cellulolytic organisms was only $23 \times 10^{4}$ micro-organisms $/ \mathrm{ml}$. Fungi and protozoa were not detected in caecal contents.

\section{Chemical composition of isolated bacteria, caecotrophes, and hard faeces and estimation of recycled nitrogen}

Fig. 1 illustrates the chemical composition (N, PB and organic matter) of caecum bacterial extracts, soft and hard faeces from animals eating the basal diet (A). Compared with hard faeces, soft faeces showed a higher content of total $\mathrm{N}(45.9 v .16 .5 \mathrm{~g} / \mathrm{kg} \mathrm{DM}), \mathrm{PB}(47.7 v .8 .25 \mathrm{mmol} / \mathrm{kg}$ $\mathrm{DM})$ and $\mathrm{PB}: \mathrm{N}(1.03 v .0 .45 \mathrm{mmol} / \mathrm{g})$. There were no differences in organic matter content between the two substrates $(P>0 \cdot 1)$. Isolated bacteria showed higher contents of $\mathrm{PB}(94.6 \mathrm{mmol} / \mathrm{kg} \mathrm{DM})$ and $\mathrm{N}(66.4 \mathrm{~g} / \mathrm{kg}$ DM) than soft faeces, but differences in PB were higher than those in $\mathrm{N}$ content, explaining the lower $\mathrm{PB}: \mathrm{N}$ ratio in soft faeces $(1.03(\mathrm{SE} 0.083) \mathrm{mmol} / \mathrm{g})$ than those values obtained in microbes $(1.42(\mathrm{SE} 0.128) \mathrm{mmol} / \mathrm{g})$.

Among diets there were no differences $(P>0 \cdot 1)$ in either DM digestibility (51.6 (SE 1.06) \%) or faecal output of both hard (41.4 (SE 1.26) g/d) and soft faeces (11.01 (SE 0.92) $\mathrm{g} / \mathrm{d}$ ). Using $\mathrm{PB}$ as a microbial marker, microbial $\mathrm{N}$ excretion in soft faeces was higher $(0.357$ (SE 0.011$) \mathrm{g} / \mathrm{d}$ ) than in hard faeces $(0.230$ (SE 0.007) g/d) and, assuming that soft faeces were fully consumed, microbial $\mathrm{N}$ intake would be about $60 \%$ of total microbial $\mathrm{N}$ synthesized in the caecum.

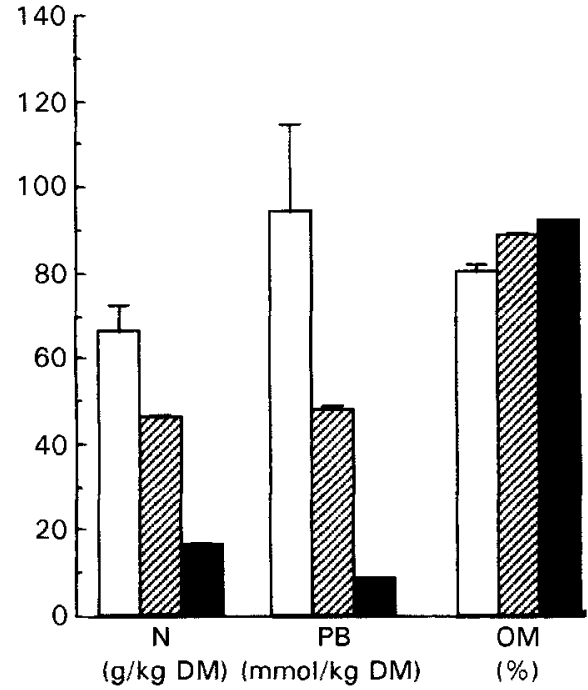

Fig. 1. Nitrogen (g/kg DM), purine bases (PB; mmol/kg DM) and organic matter (OM; \%) content of caecum bacterial extract ( $\square$ ), soft faeces ( $(\mathbb{Z})$ and hard faeces ( $\mathbf{D}$ ) from rabbits fed on a basal diet (diet A). For details of diets, see Table 1 . Values are means for seven animals, with standard deviations indicated by vertical bars.

\section{Endogenous excretion of purine derivatives}

The results from animals eating a purine-free diet are presented in Table 2. Adenine and guanine were not found in urine samples and only trace amounts of xanthine plus hypoxanthine were detected, thus the sum of allantoin and uric acid should comprise all the endogenous purine compounds excreted in urine. Total endogenous excretion of PD in six male rabbits was $588(\mathrm{SE} 40.1) \mu \mathrm{mol} / \mathrm{kg} \mathrm{W}^{0.75}$ per $\mathrm{d}$, with relative proportions of allantoin and uric acid being 0.9 and 0.1 respectively. The between-animal variation $(\mathrm{CV})$ of endogenous excretion was $6.8 \%$. Creatinine excretion during endogenous trial averaged 2.5 (SE 0.32 ) $\mathrm{mmol} / \mathrm{d}$, slightly lower than values obtained in Expt $1(2.63$ to $2.80 \mathrm{mmol} / \mathrm{d})$ but differences did not reach statistical significance.

\section{Tissue xanthine oxidase activity and purine derivative appearance in portal and peripheral blood}

With the reservation that the number of animals was small, Fig. 2 shows the increase in uric acid when xanthine was

Table 2. Expt 2. The endogenous excretion of urinary purine derivatives (PD; $\mu \mathrm{mol} / \mathrm{kg} \mathrm{W}^{0.75}$ ) by non-caecotrophagous growing rabbits fed on a semi-purified purine-free diet ${ }^{\star}$

\begin{tabular}{lcccc}
\hline Animal & LW $(\mathrm{kg})$ & Uric acid & Allantoin & Total PD \\
\hline $\mathrm{R}_{1}$ & 2.74 & 38.3 & 419 & 458 \\
$\mathrm{R}_{2}$ & 2.78 & 40.9 & 558 & 599 \\
$\mathrm{R}_{4}$ & 2.99 & 43.1 & 488 & 531 \\
$\mathrm{R}_{5}$ & 2.96 & 75.0 & 627 & 703 \\
$\mathrm{R}_{6}$ & 3.24 & 79.4 & 620 & 699 \\
$\mathrm{R}_{7}$ & 2.86 & 54.9 & 483 & 538 \\
Mean & & 55 & 532 & 588 \\
SE & & 7.33 & 33.9 & 40.1 \\
\hline
\end{tabular}

LW, live weight.

*For details of diets and procedures, see Table 1 and pp. 374-375. 


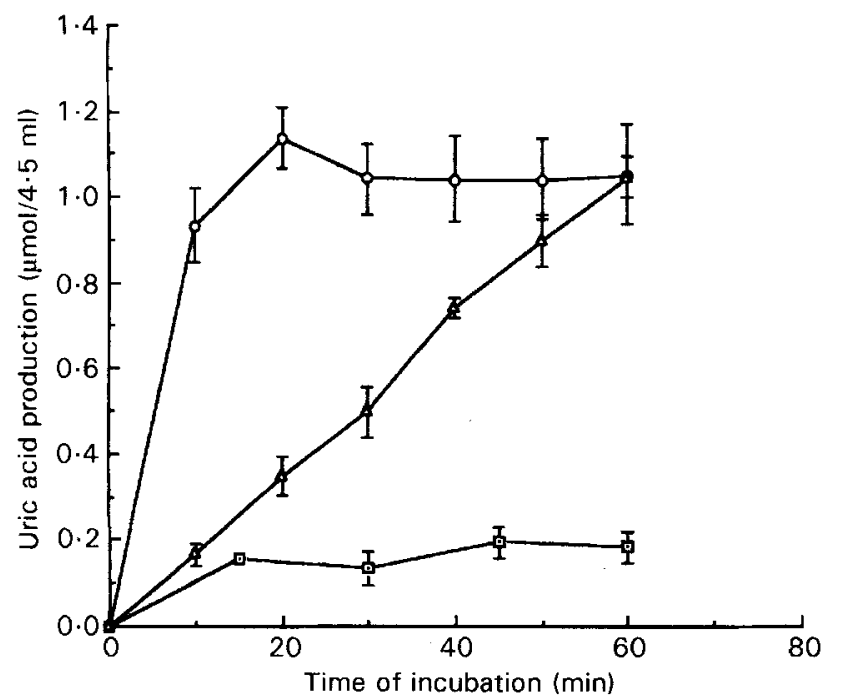

Fig. 2. Uric acid production from xanthine incubated with plasma $(\cdot \cdot)$, liver extracts $(\triangle)$ or intestinal mucosa $(O)$ from growing rabbits. Values are means for three animals, with standard deviations indicated by vertical bars. For details of procedures, see pp. 374375 .

Table 3. Expt 3. Activities ${ }^{\star}$ of xanthine oxidase (EC 1.2.3.2; $\left.X O\right)$ in plasma, liver and intestinal mucosa of growing rabbits

\begin{tabular}{llllll}
\hline Animals & $\begin{array}{c}\text { LW } \\
(\mathrm{kg})\end{array}$ & $\begin{array}{c}\text { Plasma } \\
\text { (units } / \text { l) }\end{array}$ & $\begin{array}{c}\text { Liver } \\
\text { (units/g) }\end{array}$ & $\begin{array}{c}\text { Duodenum } \\
\text { (units/g) }\end{array}$ & $\begin{array}{c}\text { Jejunum } \\
\text { (units/g) }\end{array}$ \\
\hline A & 2.7 & 0.0057 & 0.037 & 0.696 & 0.448 \\
B & 3.1 & 0.0012 & 0.037 & 0.759 & 0.404 \\
C & 2.9 & 0.0035 & 0.032 & 0.381 & 0.265 \\
& & & & & \\
Mean & 2.96 & 0.0035 & 0.036 & 0.612 & 0.37 \\
SE & 0.094 & 0.00107 & 0.0013 & 0.0954 & 0.045
\end{tabular}

LW, live weight.

"One unit of $X O$ activity was defined as $1 \mu \mathrm{mol}$ uric acid produced per min at $37^{\circ}$ with excess substrate.

incubated with different tissue extracts as a measure of their $\mathrm{XO}$ activity. Estimated values of XO activity (units/min) in plasma, intestine and liver are presented in Table 3 . The XO activity was much higher in intestine than in liver whereas plasma showed only traces of XO activity. Enzymic activity decreased along the intestine, showing a lower value in the jejunum (0.36 (SE 0.045) units $/ \mathrm{min})$ than in the duodenum $(0.61$ (SE 0.095) units/min). No XO activity was detected in kidney extracts. Table 4 illustrates the PD appearance in portal and peripheral (heart) plasma.
Allantoin concentration in normally fed rabbits was similar in both vessels $(78.2 \nu .73 .7 \mu \mathrm{mol} / \mathrm{l})$ although allantoin precursors did show a much lower concentration in peripheral than in portal blood $(P<0.01)$. On average peripheral heart blood contained $77 \%$ of the uric acid, $14 \%$ of the hypoxanthine and $26 \%$ of the xanthine present in the portal vessel. Creatinine concentrations in the two vessels were similar $(74.3$ and $73.4 \mu \mathrm{mol} / 1$ for portal and peripheral blood samples).

\section{Urinary excretion of purine derivatives at different levels of purine base intake}

Urinary excretion of total PD responded rapidly to changes in the level of PB intake (Table 5). The main increase in PD excretion, associated with dietary PB supply, was as allantoin (from 3.2 to $6.2 \mathrm{mmol} / \mathrm{d}$ ) although uric acid excretion showed a lower but significant increase (from 0.3 to $0.6 \mathrm{mmol} / \mathrm{d}$ ). As in the endogenous trial (Expt 2), xanthine and hypoxanthine excretion in urine was negligible. The proportions of allantoin and uric acid in urine samples were constant throughout the experimental period, allantoin representing $90 \%$ of total PD excretion.

$\mathrm{PD}$ excretion responds linearly to $\mathrm{PB}$ input although allantoin $(P<0.1)$ and total $\mathrm{PD}(P<0.05)$ reached a maximum at the fourth level of PB supply (diet D) and therefore the quadratic component of the response also reached statistical significance $(P<0.01)$ for both compounds (Table 5).

Creatinine excretion was not affected by the experimental treatment and averaged 1.36 (SE 0.097) $\mathrm{mmol} / \mathrm{kg}$ $\mathrm{W}^{0.75}$. The ratio total PD: creatinine concentration $(\mathrm{mol} / \mathrm{mol})$ in the urine increased linearly from 1.19 to 2.50 .

\section{Discussion}

Soft faeces production and caecal fermentation variables

Faecal excretion of soft faeces obtained in the present work $(11.0 \mathrm{~g} / \mathrm{d})$ were lower than values reported by Gidenne \& Lebas $(1987 ; 24.2 \mathrm{~g} / \mathrm{d})$ and Carabaño et al. $(1988 ; 15-29.6$ g/d) but similar to those reported by Fraga et al. (1991; $7.5-11.5 \mathrm{~g} / \mathrm{d}$ ). It is necessary to remark that most of these values correspond to a period of collection of 20-24 h whereas our values were obtained throughout a period of $72 \mathrm{~h}$. Changes in soft faeces excretion have been related to the collection procedure (Bellier \& Gidenne, 1996), age of rabbit (Gidenne \& Lebas, 1987) and diet

Table 4. Expt 3 . Concentration of purine derivatives $(\mu \mathrm{mol} / \mathrm{l})$ in portal and peripheral blood of three rabbits

\begin{tabular}{|c|c|c|c|c|c|c|c|c|c|c|}
\hline \multirow[b]{2}{*}{ Rabbit } & \multicolumn{2}{|c|}{ Allantoin } & \multicolumn{2}{|c|}{ Uric acid } & \multicolumn{2}{|c|}{ Hypoxanthine } & \multicolumn{2}{|c|}{ Xanthine } & \multicolumn{2}{|c|}{ Creatinine } \\
\hline & Portal & Heart & Portal & Heart & Portal & Heart & Portal & Heart & Portal & Heart \\
\hline $\begin{array}{l}\text { A } \\
B \\
C\end{array}$ & $\begin{array}{l}91.0 \\
89.3 \\
54.2\end{array}$ & $\begin{array}{l}91.4 \\
80.4 \\
49.4\end{array}$ & $\begin{array}{r}48.2 \\
35.1 \\
8.4\end{array}$ & $\begin{array}{l}30.0 \\
26.8 \\
14.2\end{array}$ & $\begin{array}{r}20.9 \\
12.2 \\
170.5\end{array}$ & $\begin{array}{r}8.1 \\
5.1 \\
15.6\end{array}$ & $\begin{array}{c}9.97 \\
4.8 \\
35.9\end{array}$ & $\begin{array}{l}3.2 \\
\text { ND } \\
5.9\end{array}$ & $\begin{array}{l}87.2 \\
78.2 \\
57.5\end{array}$ & $\begin{array}{l}90.6 \\
71.4 \\
58.3\end{array}$ \\
\hline $\begin{array}{l}\text { Mean } \\
\text { SE }\end{array}$ & $\begin{array}{l}78.2 \\
11.99\end{array}$ & $\begin{array}{l}73.7 \\
12.57\end{array}$ & $\begin{array}{l}30.6 \\
11.71\end{array}$ & $\begin{array}{c}23.7 \\
4.82\end{array}$ & $\begin{array}{l}67.9 \\
51.37\end{array}$ & $\begin{array}{l}9.6 \\
3.12\end{array}$ & $\begin{array}{c}16.9 \\
9.61\end{array}$ & $\begin{array}{l}4.6 \\
1.70\end{array}$ & $\begin{array}{c}74.3 \\
8.79\end{array}$ & $\begin{array}{c}73.4 \\
9.37\end{array}$ \\
\hline
\end{tabular}

ND, not detected. 
Table 5. Expt 1. Urinary excretion of purine derivatives (PD; allantoin and uric acid) and creatinine from male non-caecotrophagous rabbits fed on a grass hay-barley diet supplemented with increasing doses of nucleic acids from yeast-RNA $\dagger$

(Mean values with their pooled standard error for seven rabbits)

\begin{tabular}{|c|c|c|c|c|c|c|c|c|}
\hline \multirow[b]{2}{*}{ Diet code... } & \multirow[b]{2}{*}{ A } & \multirow[b]{2}{*}{$\mathrm{B}$} & \multirow[b]{2}{*}{$C$} & \multirow[b]{2}{*}{$\mathrm{D}$} & \multirow[b]{2}{*}{$E$} & \multirow[b]{2}{*}{ SE } & \multicolumn{2}{|c|}{$\begin{array}{l}\text { Statistical signifi- } \\
\text { cance of effect of PB } \\
\text { supplementation }\end{array}$} \\
\hline & & & & & & & Lin & Quad \\
\hline PB intake $(\mathrm{mmol} / \mathrm{d})$ & $2 \cdot 32$ & 4.70 & 6.50 & 8.48 & $10 \cdot 30$ & 0.301 & $\star \star * *$ & NS \\
\hline \multicolumn{9}{|l|}{ Urinary excretion } \\
\hline Allantoin $(\mathrm{mmol} / \mathrm{d})$ & 3.18 & 4.17 & $5 \cdot 31$ & $6 \cdot 10$ & $6 \cdot 21$ & 0.217 & $* \star *$ & $* *$ \\
\hline Uric acid $(\mathrm{mmol} / \mathrm{d})$ & 0.31 & 0.38 & 0.36 & 0.62 & 0.60 & 0.082 & $\star \star$ & NS \\
\hline Total PD $(\mathrm{mmol} / \mathrm{d})$ & 3.34 & 4.55 & 5.67 & $6 \cdot 71$ & 6.80 & 0.300 & $\star \star \star *$ & ${ }^{\star}$ \\
\hline$\left(\mathrm{mmol} / \mathrm{kg} \mathrm{W} \mathrm{W}^{0.75}\right)$ & 1.62 & $2 \cdot 21$ & 2.79 & $3 \cdot 33$ & 3.36 & 0.191 & $* \star *$ & NS \\
\hline Creatinine $(\mathrm{mmol} / \mathrm{d})$ & 2.76 & 2.63 & 2.92 & 2.80 & 2.72 & 0.240 & NS & NS \\
\hline$\left(\mathrm{mmol} / \mathrm{kg} \mathrm{W}^{0.75}\right)^{\prime}$ & 1.36 & 1.29 & 1.43 & 1.37 & 1.36 & 0.097 & NS & NS \\
\hline Allantoin/creatinine & 1.19 & 1.73 & 2.01 & 2.57 & 2.50 & 0.237 & 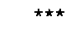 & 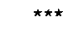 \\
\hline
\end{tabular}

Lin, linear; Quad, quadratic; $P B$, purine bases.

${ }^{\star} P<0.05 ;{ }^{*} P<0.01 ;{ }^{* \star *} P<0.001$.

tFor details of diets and procedures, see Table 1 and pp. 374-375.

characteristics (Carabaño et al. 1988). Thus, our experimental procedures, which required prevention of caecotrophagy during a period of $6 \mathrm{~d}$ before soft faeces collection, may have affected to some extent the daily excretion of soft faeces. In any case, the fermentation variables in caecal content ( $\mathrm{pH}$ and VFA content) were similar to those reported by other workers (Jehl \& Gidenne, 1996) and the $\mathrm{NH}_{3}$ concentration in particular was also in the range described in the literature (Carabaño et al. 1988; Fraga et al. 1991; Jehl \& Gidenne, 1996) and adequate for optimal microbial synthesis $(5-15 \mathrm{mg} / 100 \mathrm{ml}$; Balcells et al. 1993).

A single microbial isolate was obtained from a mixed sample of the whole caecal population. The chemical composition of this isolate was within the range reported in the literature for rumen micro-organisms (Legay-Carmier \& Bauchart, 1989; Pérez et al. 1996), but closer to the values described for an adherent population than for liquidassociated bacteria (Pérez et al. 1996). Assuming that dietary PB are mostly digested in the small intestine (Storm et al. 1983) or are quickly degraded by caecal fermentation (Surra et al. 1997), PB in faeces can be considered to be of microbial origin, and used as a microbial marker. Thus, the higher concentration of PB in soft than in hard faeces confirms the high efficiency of the large intestine in rabbits to concentrate the caecum microbial yield in the soft faecal material, allowing recycling of microbial-N through caecotrophagy. In spite of this, about $40 \%$ of the caecal net microbial synthesis (soft + hard faeces PB) was lost throughout the excretion of hard faeces.

\section{Endogenous excretion of purine derivatives}

Although the animals lost weight during the experiment, no other apparent disturbances were observed. The endogenous excretion observed in the present study was similar $\left(588 \mu \mathrm{mol} / \mathrm{kg} \mathrm{W}^{0.75}\right)$ to those values reported in cattle $\left(500-514 \mu \mathrm{mol} / \mathrm{kg} \mathrm{W}^{0.75}\right)$ by Chen et al. $(1990 \mathrm{~b})$ and Giesecke et al. (1993), but much higher than those measured in sheep $\left(165-202 \mu \mathrm{mol} / \mathrm{kg} \mathrm{W}^{0.75}\right.$; Chen et al. 1990b; Balcells et al. 1991), pigs (166 and $199 \mu \mathrm{mol} / \mathrm{kg}$
$\mathrm{W}^{0.75}$; Chen et al. 1990b; Martín-Orúe et al. 1995) and man (70-80 $\mu \mathrm{mol} / \mathrm{kg} \mathrm{W}$ W $^{0.75}$, assuming $70 \mathrm{~kg} \mathrm{LW}$; Zollner, 1982). Higher values were reported by Greife (1980) in rats $\left(970 \mu \mathrm{mol} / \mathrm{kg} \mathrm{W}^{0.75}\right)$. Species differences in the urinary endogenous excretion of PD were also evident in the form of the derivatives excreted. In sheep and pigs reusable-PD (xanthine plus hypoxanthine) accounted for a considerable proportion of total PD (Chen et al. 1990b; Balcells et al. 1991); whereas in cattle, buffalo (Chen et al. 1996) and rabbits both compounds were negligible. Changes in the magnitude and profile of the endogenous $\mathrm{PD}$ have been related to differences in the tissue $\mathrm{XO}$ activity.

\section{Tissue xanthine oxidase activities and blood concentration of purine derivatives}

The present study in rabbits showed differences in the level of XO activity in plasma, liver and intestine, and also a decreasing level of activity between duodenum and jejunum (Table 3); XO activity was negligible in kidney. PD concentrations in plasma samples were higher than values reported previously by $\mathrm{Al}$-Khalidi \& Chaglassian (1965) but these differences could be explained by the modification of the analytical procedure consisting of the inclusion of L-histidine to prevent inhibition of $\mathrm{XO}$ by excess substrate (Chen et al. 1996). The authors are unaware of additional data on tissue XO activity in rabbit tissues, but present values are similar to those reported in the rat. Mohamedali et al. (1993) reported a much higher $\mathrm{XO}$ activity in rat duodenum ( $3.29 \mathrm{units} / \mathrm{g}$ ) than in liver (about 0.20 units $/ g$ ) whereas only traces of XO activity were detected in kidney. These authors also found that enzyme activity was highest in the duodenum and decreased across the small intestine with only trace amounts being found in hindgut.

Among species, Chen et al. (1996) reported a higher XO activity in cattle or buffalo than in sheep. Whereas sheep showed only trace amounts of enzyme, buffalo and cattle had high levels of XO activity in liver $(0.44$ and 0.30 units/g), intestinal mucosa $(0.31$ and 0.18 units/g) 


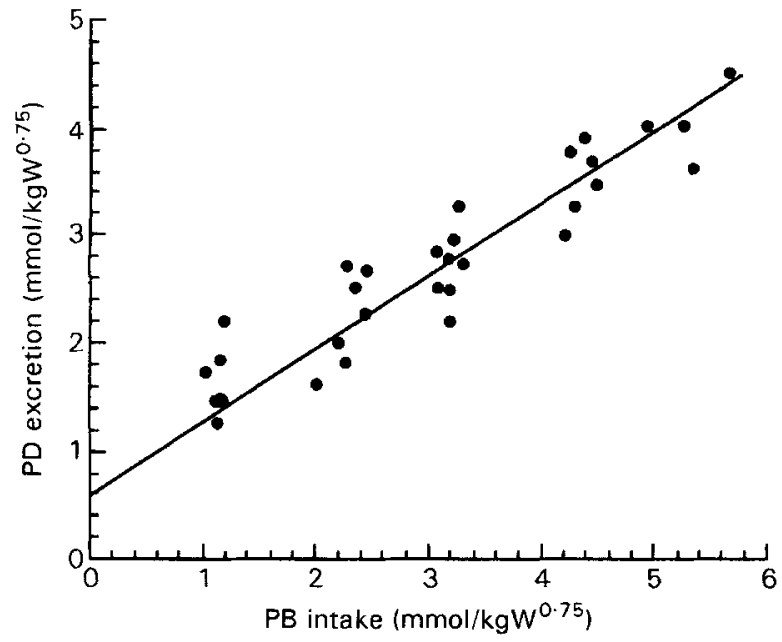

Fig. 3. Urinary excretion of purine derivatives (PD) in relation to intake of purine bases $(\mathrm{PB})$ in rabbits $\left(\mathrm{mmol} / \mathrm{kg} \mathrm{W}^{0.75}\right)$. The relationship is described by the equation $y=0.59+0.67 x, R^{2}$ $0.86, n 32$.

and plasma ( 24.5 and 1.4 units/1, respectively). In rabbits the high XO activity determined in intestinal mucosa suggests that dietary nucleic acid bases are rapidly degraded to oxidized derivatives across the intestinal mucosa and hepatic metabolism, but small significant amounts of reusable PD (xanthine plus hypoxanthine; Table 4) were still detected in peripheral blood.

\section{Relationship between excretion of purine derivatives and purine intake}

Three animals showed a biased urinary recovery of ingested PB when they were fed on the highest level of PB intake (diet E). These animals received the higher levels of dietary PB supply during the earlier periods of the experiment. Because of the high level of dietary PB supply and the significant changes in intestinal structure and function with rabbit ageing (Thomson, 1986), these values were removed from all calculations. In any case, when data from these animals were included, both intercept and incremental recovery were not significantly different to the presented equation, but the correlation was lower $\left(r^{2}\right.$ 0.699).

Daily excretion of total PD $\left(y ; \mathrm{mmol} / \mathrm{kg} \mathrm{W}^{0.75}\right)$ was correlated linearly with intake of total PB $(x ; \mathrm{mmol} / \mathrm{kg}$ $\mathrm{W}^{0.75}$ ), since the inclusion of a curvilinear component did not significantly improve the adjustment. It was assumed that the intercept $(x=0)$ was equal to endogenous excretion $\left(0.588 \mathrm{mmol} / \mathrm{kg} \mathrm{W}^{0.75}\right)$. The resultant equation was:

$$
\begin{gathered}
y=0.59(\text { SE 0.136) }+0.67 \text { (SE 0.018) } x \\
\left(r^{2} 0.860, \text { RSD 0.338, } n\right. \text { 32; Fig. 3). }
\end{gathered}
$$

Incremental recovery of ingested $(0.67)$ or absorbed $\mathrm{PB}$ (0.73), assuming the digestibility ratio 0.91 (Chen et al. $1990 a$ ), indicates that absorbed PB are not fully recovered in the urine and a significant fraction may be lost through other routes, for example saliva (Chen et al. 1990a; Surra et al. 1997) or through the hindgut (Berlin \& Hawkins, 1968).
A linear model to describe the relationship between urinary excretion and intake of purine compounds has been used in man (Zollner, 1982), other single-stomached animals (Giesecke \& Timeyer, 1982) and cattle (Verbic et al. 1990). This previous response model assumes that there is a constant endogenous excretion of PD coming from de novo synthesis processes defining the balance between salvage pathway and de novo synthesis at a cellular level. Thus it has been suggested that $\mathrm{XO}$ activity in the different tissues not only degrades purines to nonrecoverable PD but also regulates the balance between degradation and salvage of purine compounds (Kaminski \& Jezewska, 1979). Rabbits showed a similar XO profile to those seen in rat, man and cattle, and then a similar model to those described in these species would be expected.

If the urinary excretion of $P D$ is a linear function of duodenal flow of PB and it is assumed that PBdigestibilities of microbial and dietary sources are equal, microbial-N intake from caecotrophagy can be estimated by subtracting those purines ingested with feed from the duodenal PB-flow. The following equation based on the response model (Fig. 3) and the PB: $\mathrm{N}$ ratio obtained in caecal flora $(1.42 \mathrm{mmol} / \mathrm{g})$ is suggested:

microbial-N intake $\left(\mathrm{g} / \mathrm{kg} \mathrm{W}^{0.75}\right)=1.05 y_{1}-0.70 x_{2}-0.6$, where $y_{1}$ is PD excreted in urine $\left(\mathrm{mmol} / \mathrm{kg} \mathrm{W}^{0.75}\right)$ and $x_{2}$ is dietary intake of $\mathrm{PB}\left(\mathrm{mmol} / \mathrm{kg} \mathrm{W}^{0.75}\right)$.

The precision of the reported relationship between purine intake and urinary excretion of PD and the significant contribution of microbial $\mathrm{PB}$ to the total purine intake support this method as a simple and useful tool to estimate, under practical conditions, the microbial protein intake of growing rabbits.

\section{Acknowledgements}

The authors wish to thank J. A. Guada and M. Fondevila for the critical review of this manuscript.

\section{References}

Al-Khalidi UAS \& Chaglassian TH (1965) The species distribution of xanthine oxidase. Biochemical Journal 97, 318-320.

Balcells J, Fondevila M, Guada JA, Castrillo C \& Surra JC (1993) Urinary excretions of purine derivatives and nitrogen in sheep given straw supplemented with different sources of carbohydrates. Animal Production 57, 287-292.

Balcells J, Guada JA, Castrillo C \& Gasa J (1991) Urinary excretion of allantoin and allantoin precursors by sheep after different rates of purine infusion into the duodenum. Journal of Agricultural Science, Cambridge 116, 309-317.

Balcells J, Guada JA, Peiró JM \& Parker DS (1992) Simultaneous determination of allantoin and oxypurines in biological fluids by high-performance liquid chromatography. Journal of Chromatography 575, 153-157.

Bellier R \& Gidenne T (1996) Consequences of reduced fibre intake on digestion, rate of passage and caecal microbial activity in the young rabbit. British Journal of Nutrition 75, 353-363.

Berlin RD \& Hawkins RA (1968) Secretion of purines by the small intestine: general characteristics. American Journal of Physiology, 215 932-941. 
Box GEP, Hunter WG \& Hunter IS (1978) Statistics for Experimenters. An Introduction to Design, Data Analysis and Model Building. New York: J. Wiley \& Sons, Inc.

Bryant MP \& Burkey LAC (1953) Cultural methods and some characteristics of some of the more numerous groups of bacteria in the bovine rumen. Journal of Dairy Science 36, 205-217.

Carabaño R, Fraga MJ, Santoma G \& de Blas C (1988) Effect of diet on composition of cecal contents and on excretion and composition of soft and hard feces of rabbits. Journal of Animal Science 66, 901-910.

Chaney AL \& Marbach EP (1962) Modified reagents for determination of urea and ammonia. Clinical Chemistry $\mathbf{8}$, $130-132$.

Chen XB, Hovell FDDeB, Ørskov ER \& Brown DS (1990) Excretion of purine derivatives by ruminants: effect of exogenous nucleic acid supply on purine derivative excretion by sheep. British Journal of Nutrition 63, 131-142.

Chen XB, Ørskov ER \& Hovell FDDeB (1990) Excretion of purine derivatives by ruminants: endogenous excretion, differences between cattle and sheep. British Journal of Nutrition 63, 121-129.

Chen XB, Samarawera L, Kyle DJ, Ørskov ER \& Abeygunawardene $H$ (1996) Urinary excretion of purine derivatives and tissue xanthine oxidase (EC 1.2.3.2) activity in buffaloes (Bubalis bubalis) with special reference to differences beween buffaloes and Bos taurus cattle. British Journal of Nutrition 75 , 397-407.

Fraga MJ, Pérez de Ayala P, Carabaño R \& de Blas JC (1991) Effect of type of fiber on the rate of passage and on the contribution of soft feces to nutrient intake of finishing rabbits. Journal of Animal Science 69, 1566-1574.

Furth-Walker D \& Amy NK (1987) Regulation of xanthine oxidase activity and inmunologically detectable protein in rats in response to dietary protein and iron. Journal of Nutrition 117, 1697-1705.

Gidenne T \& Lebas F (1987) Estimation quantitative de la caecotrophie chez le lapin on croissance: variations en founction de l'âge (Quantitative estimation of the caecotrophy in growing rabbits: age function variations). Annales de Zootechnie 36, 225-236.

Giesecke D, Balsliemker J, Südekum KH \& Stangassinger M (1993) Plasma level, clearance and renal excretion of endogenous and ruminal purines in the bovine. Journal of Animal Physiology and Animal Nutrition 70, 180-189.

Giesecke D \& Tiemeyer W (1982) Availability and metabolism of purines of single-cell proteins in monogastric animals. Proceedings of the Nutrition Society 41, 319-327.

Greife HA (1980) Nitrogen utilization of microbial nucleic acids in the growing rat. In Proceedings of the 3rd EAAP Symposium on Protein Metabolism and Nutrition, Braunschweig, F.R. Germany, May 1980. European Association of Animal Production, Publication no. 27, pp. 159-167 [HJ Oslage and K Rohr, editors]. Braunschweig: Institute of Animal Production.

Hörnicke H \& Björnhag G (1980) Coprophagy and related strategies for digesta utilization. In Digestive Physiology and Metabolism in Ruminants, p. 708 [Y. Ruckebusch and P. Thivend editors]. Lancaster: MTP Press.

Jehl N \& Gidenne T (1996) Replacement of starch by digestible fibre in feed for the growing rabbit 2. Consequences for microbial activity in the caecum and on incidence for digestive disorders. Animal Feed Science and Technology 61, 193204.

Jouany JP (1982) Volatile fatty acid and alcohol determinations in digestive contents, silage juices, bacterial cultures and anaerobic fermentors contents. Science des Aliments 2, 131-144.

Kaminski ZW \& Jezeswka MM (1979) Intermediate dehydrogenase-oxidase form of xanthine oxidoreductase in rat liver. Biochemical Journal 181, 177-182.

Lindberg JE, Bristav H \& Manyenga AR (1989) Excretion of purines in the urine of sheep in relation to duodenal flow of microbial protein. Swedish Journal of Agricultural Research 19, 45-52.

Legay-Carmier F \& Bauchart D (1989) Distribution of bacteria in the rumen contents of dairy cows given a diet supplemented with soya-bean oil. British Journal of Nutrition 61, 725740.

Martín-Orúe SM, Balcells J, Guada JA \& Castrillo C (1995) Endogenous purine and pyrimidine derivative excretion in pregnant sows. British Journal of Nutrition 73, 375-385.

Mohamedali KA, Guicherit OM, Kellems RE \& Rudolph FB (1993) The highest levels of purine catabolic enzymes in mice are present in the proximal small intestine. Journal of Biological Chemistry 268, 23728-23733.

Pérez JF, Balcells J, Guada JA \& Castrillo C (1996) Determinations of rumen microbial- $\mathrm{N}$ production in sheep. A comparison of urinary purine excretion with methods using ${ }^{15} \mathrm{~N}$ and purine bases as markers of microbial-N entering the duodenum. British Journal of Nutrition 75, 699-709.

Proto V, Gargano D \& Gianani L (1968) La coprofagia del coniglio sotto posto a differenti diete (Coprophagy in the rabbit under different diets). Produccion Animal 7, 157.

Reeds PJ, Burrin DG, Stoll B, Jahoor F, Wykes I, Henry J \& Frazer M (1997) Enteral glutamate is the preferential source for mucosal glutathione synthesis in fed piglets. American Journal of Physiology 273, 408-415.

Steel RGD \& Torrie JH (1980) Principles and Procedures of Statistics, 2nd ed. New York: McGraw-Hill.

Storm E, Brown DS \& Ørskov ER (1983) The nutritive value of rumen micro-organisms in ruminants. 3. The digestion of microbial amino and nucleic acids in, and losses of endogenous nitrogen from, the small intestine of sheep. British Journal of Nutrition 50, 479-485.

Surra JC, Guada JA, Balcells J \& Castrillo C (1997) Effects of post ruminal fermentation of the faecal and urinary excretion of purines. Animal Science 65, 383-390.

Thomson AB (1986) Early nutrition and intestinal transport function: effect of low-cholesterol diet. Journal of Laboratory and Clinical Medicine 107, 365-377.

Van Soest PJ, Robertson JB \& Lewis RA (1991) Methods for dietary fiber, neutral detergent fiber and non-starch polysaccharides in relation to animal nutrition. Journal of Dairy Science 74, 3583-3597.

Verbic J, Chen XB, Macleod NA \& Ørskov ER (1990) Effect of microbial nucleic acid infusion on purine derivative excretion by steers. Journal of Agricultural Science, Cambridge, 114, 243-248.

Zollner N (1982) Purine and pyrimidine metabolism. Proceedings of the Nutrition Society 41, 329-342. 